\title{
Three Comments on Storm "The Economics and Politics of Social Democracy: A Reconsideration"
}

\author{
Joseph Halevi ${ }^{\dagger}$ and Peter Kriesler * \\ Duncan Foley ${ }^{\S}$ \\ Thomas Ferguson ${ }^{g}$
}

Working Paper No. 123

May 8, 2020

\begin{abstract}
This Working Paper presents three separate comments on Servaas Storm's "The Economics and Politics of Social Democracy: A Reconsideration". The first is by Joseph Halevi and Peter Kriesler; the second is by Duncan Foley; and the third is by Thomas Ferguson.
\end{abstract}

JEL Codes: E6, E10, E12, H3, N10, P11

Keywords: social democracy, wage-led growth, profit-led growth, NAIRU economics, Europe 1945- , New Labor.

https://doi.org/10.36687/inetwp123

\footnotetext{
${ }^{\dagger}$ Professor Emeritus University of Sydney; Professor, International University College of Turin. josephhalevi53@gmail.com.

* Associate Professor, University of New South Wales, p.kriesler@unsw.edu.au

$\S$ Professor of Economics, New School for Social Research

' Professor Emeritus at the University of Massachusetts, Boston; Director of Research at the Institute for New Economic Thinking; Senior Fellow at Better Markets.
} 


\section{Growth, Demand, and Wages}

\section{Joseph Halevi and Peter Kriesler}

Much of the argument of Servaas Storm's paper is predicated on the dichotomy between profit-led and wage-led growth. In our view, this is a mistaken antinomy. Growth comes from increased demand - which requires increases in consumption, investment, net exports or net government expenditure- or any combination of these. The idea that increased wages will squeeze profits is only true at full employment. As Kalecki clearly shows, total profits are determined by capitalists' expenditure decisions - i.e., what they spend on their consumption and investment; and also on net government expenditure and net exports. Changes in wages have no impact on total profits - all they do is influence the distribution of profits between sectors.

The argument in the paper conflates profit share with the rate of profits - but these are quite different and do not necessarily move in the same direction. It is correct that increases in real wages, ceteris paribus, will reduce the profit share, but not necessarily the rate of profits or total profits. In the short run, when the capital stock is given, changes in total profits will be associated with changes in profit rates. Total profits are determined by the expenditure decisions of capitalists - not by the mark up or share of profits. Increases in these will simply influence the sectoral allocation of profits (see, for example, Kriesler 1996 and Robinson 1977) and may increase unemployment and output. ${ }^{1}$

To accept the viewpoint behind profit-led growth implies that a reduction in real wages can lead to increased employment and output - a view which both Kalecki and Keynes rejected. A reduction in real wages, while it may increase profits in the capitalist consumption and investment sectors, will reduce profits by the equivalent amount in the wage good sector - also reducing employment and output in that sector while leaving them unchanged elsewhere. The idea that aggregate demand will fall if real wages rise lacks theoretical and empirical foundations - yet it is the basis of the argument for profit led growth!

In fact there is no trade-off between higher real wages and profitability and employment except when the economy is at full employment or full capacity. The Thatcher and Reagan policies referred to in Storm's paper exasperated, not alleviated, the problem. That is why both are

\footnotetext{
1 "The most important point in Kalecki's analysis is the demonstration that the overall rate of profit cannot be raised by raising the degree of monopoly. A higher proportion of profit margins leads to lower real wages and lower utilization of plant, not to a higher overall total profit." [Robinson (1969) p. 261]
} 
associated with lower employment and growth, although Reagan implemented military Keynesianism with demand significantly boosted with armaments expenditures.

While higher real wages may reduce a country's international competitiveness, this will depend both on foreign prices and the exchange rate. So most of the arguments of the importance of profits in Section 3 of the paper are correct, but the idea that this requires a fall in real wages is not. Similarly, it is not an argument against redistribution, given the higher marginal propensities to consume of lower income earners - any redistribution will increase consumption, aggregate demand and, therefore profits.

In other words, policies to restrain wages will almost always lead to reduced output, employment and growth - unless they are compensated by increases in either net exports or net government expenditure. In fact, the policies discussed in the paper are also associated with falls in investment in real capacity and it is this which explains the fall in productivity. With most investment going into buildings and finance, the capital required to boost the productivity of labor was simply not forthcoming.

The paper suggests that labor costs and profit are the main determinants of and influences on investment. However, this ignores the key role that expected demand plays in determining investment in productive capacity - it is only if this is expected to increase that capitalists have a reason to invest. So any policy which reduces labor costs or increases profitability while reducing expected demand is unlikely to stimulate investment.

It is also important to note that the rejection of Keynesian ideas was not due to stagflation - the Samuleson/Solow Phillips curve provided a better explanation of stagnation than did the competing explanation from Friedman. Rather, it was, as Kalecki predicted, the pursuit of policies which recreate the reserve army of labor. In other words, the policy regime from the 1970s was not the result of the failure of Keynesianism. Keynesian policies - incomes policy + government stimulation would have solved the stagnation problem. Rather it was selling policies which intentionally created unemployment so as to reaffirm the power of the capitalist class. Similarly, neoliberal polices have all, at their heart, the idea that either unemployment or precarious employment are necessary in order to reduce the power of workers.

In Storm's paper, the key equations are 1-3 which end with a relationship where increases in real wages reduce the profit rate - which is quite anti-Kaleckian. There are some problems with the notions of normal capacity and output - but they are irrelevant to the main issue. The reason for the relationship in the equations is simple - the assumption that real wages do not affect $\mathrm{U}-$ the level of capacity utilization. Clearly, any change in wages will lead to a change in U - and so they are not independent variables. An increase in w will lead to consumption increasing, and therefore $U$ increasing, and vice versa for a fall. This removes what the paper calls "the dilemma facing social democracy", and undermines the subsequent arguments of the paper. 
We have seen that there cannot be such a thing as a profit led growth. Profits depend on investment. Indeed under the extreme assumption that all profits and no wages are saved, profits are equal to investment (in a closed economy with no trade). In Kalecki's main model, profits result from capitalists' consumption spending and investment, as shown in his very first equation published in 1933 (Kalecki, 1933, in Kalecki 1971a)

\section{$\mathrm{P}=\mathrm{Cc}+\mathrm{A}$.}

Where $\mathrm{P}$ are gross profits, $\mathrm{Cc}$ is capitalists' consumption, and $\mathrm{A}$ is gross accumulation, akin to gross investment in standard macroeconomics.

As noted above, total profits are therefore determined by capitalists' spending on consumption and investment, hence profits do not drive investment. Effective demand does, especially through capitalists' expenditure.

Can we now envisage wage led growth? In principle yes, as long as there is unused capacity in the wage goods sector, which in a salaried economy produces most of the mass consumption goods including autos, appliances, airline tickets, etc. Furthermore, if spare capacity still persists in the capital goods sector while the consumption sector is approaching full capacity, companies may place additional orders for machines, thereby lifting profits in the capital goods sector while expanding the output potential in the consumption goods one. Yet in order to internalize the fact that a wage push could generate higher demand and, for any given level of investment, higher profits in the consumption goods sector, firms would have to behave like a macroeconomic whole. Whereas they only see the increase in wages above productivity as a squeeze on profit margins.

In his last, posthumously published Kyklos paper Kalecki (1971b) put forward a strong case for labor militancy arguing that unions should not accept the corporate view that higher wages bring about a lower level of profits. This is because profits are determined by the level of investment, which in turn is the product of past decisions. Thus, at any given point of time, higher wages shift profits from the capital goods and luxury goods sectors to those of mass consumption. In so doing the level of capacity utilization rises in the latter sector bringing about also an increase in employment. The existence of large oligopolistic formations may significantly limit the working of this process as firms tend to pass cost increases onto prices. Hence Kalecki argued that unions should not just push for higher wages regardless of the contrary position, but ought to get involved in tax policies and in the subsidization of essential wage goods.

It must be pointed out that Kalecki's argument is cast in terms of a short period analysis which he considered, just as Keynes did, the frame of reference for studying economic dynamics that he viewed as a chain of short period situations. He also wrote the paper shortly after the May '68 general strike in France and during the beginning of the hot autumn in Italy in 1969. In the paper there is a message to the trade unions not to accept the tenet that more wages imply less 
profits. Its implementation required a systemic class struggle conducted at both the economic and the institutional levels. Nowhere in the Kyklos paper does the view that wage led expansion is a natural phenomenon, like a law of economic dynamics, appear.

These theoretical points can be reinforced with a closer look at the European context that Storm discusses. ${ }^{2}$ After World War II Europe was rebuilt around the principle of export led growth, although its theorization had to wait until Kaldor's (1966) celebrated Cambridge Inaugural Lecture. There were three phases in this process. The first phase spans from the Marshall Plan to the end of the European Payment Union (EPU), both devised by the US and by Robert Triffin and Charles Kindleberger in particular. The EPU facilitated both exports and imports by creating a mechanism favoring the recycling of surpluses (Milward 1992). The second phase began when, still under a regime of fixed exchange rates, the EPU ceased to exist by the end of 1958. From that moment onward economic policies were aimed at fostering net surpluses.

With the exception of Germany, the Benelux and Sweden, persistent surpluses were rare so that countries reacted pro-cyclically. In this context, with the compass set on exports as a priority vis à vis domestic effective demand and employment, wages played a secondary role. In some cases as in Italy and also in Britain and France, wage increases outside of what companies deemed to be efficient rises, were seen as a negative factor both by company executives and by state bureaucrats. When they could not be resisted or tamed companies accepted them by shifting the burden onto investment. With the onset of competitive devaluations in the 1970s, along with the inflation and devaluation cycle on one hand (Italy) and the price stability strategy on the other (West Germany), wages ceased altogether to be considered as a positive factor in policy making. That marked the beginning of the third phase from labor's standpoint. This phase is still with us and consists in the systemic decline of labor's bargaining power. The view that more profits come out of lower wages and that more profits lead to greater investment, has been internalized within the trade union movement as well and, of course, by the social democrats.

Storm's paper puts forward the case that the social democracies abandoned wage led growth in favor of a profit-led regime counting on the reinvestment of profits. It is difficult see how such a wage led dynamic can be grafted onto Europe's growth history. Perhaps some of that existed in Sweden, with the idea of squeezing profit margins in order to foster innovations and external competitiveness. Yet the macroeconomic objective was primarily that of achieving export surpluses (Gosta et al, 1973).

The growth factors in Europe have been public expenditure and investment, the latter tied significantly to export objectives. But global export objectives cancel out, so that unless there is a country so big and possessing a universally acceptable currency that it can generate limitless imports, the global factors sustaining growth are investment and public expenditure. In France

\footnotetext{
${ }^{2}$ For details on much of what follows, see (Halevi, 2019a; 2019b; 2019c).
} 
during 1968 the big wage rises did not hamper the economy to any significant extent. There are instead indications to the contrary, although the wage rises contributed to increasing net imports from the rest of Europe due to higher demand but not to a balance of payments crisis level. Just the same, the message retained by the government and the corporations was "never again."

It is very difficult to find cases of wage led growth as the product of a rational policy. Such a stance would require a strong institutional system tilted towards the trade unions. There are also reasons to doubt that the acceptance by the social democracies from the mid-1970s onward that profits should be given priority, was intentionally based on the idea that higher profits led to higher investment and, afterwards, as expressed in Storm's quote from Helmut Schmidt, to higher employment. The social democracies accepted, in fact, the creation of a reserve army of labor often justifying such an acceptance with the above mentioned theory. ${ }^{3}$ We know however that the causation is in the opposite direction whereby higher investment leads to larger profits. Negative changes in the wage shares do not lead to higher investment as they can be used to strengthen profit margins under price stability and disinflationary objectives. In the best of cases the social democracies shared what Kaldor (1983) famously called the Marxist argument developed by the conservatives regarding the flawed rationale for the deliberate creation of unemployment through monetarist policies. The social democracies cooked that rationale in a sauce of a different color that tasted just as bad as the monetarist cum conservative one.

A last comment concerns the closing statement in the paper that Europe's growth is wage driven. It is not. It is export driven because a State of Europe does not exist and every country considers the market of the rest of Europe as external to itself. Hence Europe is always prey to the fallacy of composition on the external accounts within the same European Union.

\section{References}

Gosta, E., Faxen, K., Olof, O. and Clas-E. (1973) Wage Formation and the Economy, London, Allen and Unwin.

Halevi, Joseph. (2019a) “The Political Economy of Europe Since 1945,” Institute for New Economic Thinking Working Paper No. 100, https://papers.ssrn.com/sol3/papers.cfm?abstract id=3482113

Halevi, Joseph. (2019b) "Europe From 1957 to 1979: From the Common Market to the European Monetary System," Institute for New Economic Thinking, Working Paper No. 101, https://papers.ssrn.com/sol3/papers.cfm?abstract id=3482147

\footnotetext{
${ }^{3}$ Not even always - as the French case showed when in the mid-1980s the Socialists engineered the policy of competitive disinflation.
} 
Halevi, Joseph (2019c) "From the EMS to the EMU and....To China," Institute for New Economic Thinking Working Paper, No. 102, https://papers.ssrn.com/sol3/papers.cfm?abstract id=3482210

Kaldor, N. (1966) Causes of the Slow Rate of Economic Growth of the United Kingdom. An Inaugural Lecture. Cambridge: Cambridge University Press.

Kaldor N. (1983) The Economic Consequences of Mrs. Thatcher. Speeches at the House of Lords 1979-1983. London: Duckworth.

Kalecki, Michal (1971a) "Outline of a theory of the business cycle", originally published in 1933, in Michal Kalecki, Selected Essays on the Dynamics of the Capitalist Economy 1933-1970, 1-14. Cambridge (UK): Cambridge University Press.

Kalecki, Michal (1971b) "Class struggle and distribution of national income”, originally published in Kyklos 1970, in Michal Kalecki, Selected Essays on the Dynamics of the Capitalist Economy 1933-1970, 156-64. Cambridge (UK): Cambridge University Press.

Kriesler, P. (1996) "Microfoundations: a Kaleckian perspective" in King, J. (Ed) An Alternative Macroeconomic Theory: the Kaleckian model and Post-Keynesian Economics Kluwer: Boston, 55-72, reprinted in Halevi, J., Harcourt, G.C., Kriesler, P.,and Nevile J. (2016) Post-Keynesian Essays from Down Under Volume I: Essays on Keynes, Harrod and Kalecki: Theory and Policy in an Historical Context 161-76. Palgrave Macmillan.

Milward, Alan (1992). The European Rescue of the Nation-State, London: Routledge.

Robinson, J. (1969) "A Further Note," Review of Economic Studies, 36, 260-262.

Robinson, J. 1977 "Kalecki on the economics of capitalism" Oxford Bulletin of Economics and Statistics, 39, 7-17 


\section{Structural Changes and Social Democratic Decline}

\section{Duncan K. Foley}

Servaas Storm's essay has very pertinent things to say about the political decline of social democratic parties, particularly on the role of macroeconomic aggregate demand policy on political economic outcomes, but it seems to me to be somewhat one-dimensional in neglecting more structural issues. Storm argues effectively that austerity economics in particular has had a toxic political effect on center-left parties infected by it. This story, which Storm's work has followed for many years, is a key to understanding recent political economic developments in postindustrial capitalist societies.

It would help Storm's case to situate it in a deeper historical background. For example, the history of the path through which social democratic parties achieved the politically central role they did after WWII, and how those developments connect with the events in the 1920s and 1930s, seem centrally relevant to the discussion, since this history has important resonances with current politics. The predecessors of the post-World War II social democratic parties had been the main parties of government in Europe in the nineteen-twenties, but were unable to stabilize a hegemonic role in the face of the economic crises after World War I and unremitting pressure from extreme political movements on both the Left and the Right. The European post-World War II political systems, somewhat artificially shaped by U.S. reconstruction policy, cast revived social democratic parties as competitors for power with revived center-right parties. The defeated and discredited Fascist and Nazi parties presented no credible threat from the extreme right, and the Cold War largely neutralized Communist politics on the extreme left. Is it so surprising, however, that the pre-World War II patterns eventually re-appeared in the form of populist politics?

Wouldn't one expect some decline in support of the social democratic parties due to demographics and structural changes? Higher income people tend to vote more conservative, and incomes rose quite rapidly in the 1960s and 1970s in the European countries. The social democratic parties responded to some degree to this demographic pressure by moving to the right in adopting increasingly neoliberal economic policies, but this maneuver now seems to have been one of the main reasons for the sorry state of the social democrats, as Storm explains in his discussion of macroeconomic policy.

Storm presents the whole story predominantly from the perspective of macroeconomics and macroeconomic policy, which is where the one-dimensionality creeps in. It's not clear from a Keynesian point of view why the wage-led vs profit-led question makes a whole lot of macroeconomic difference, since monetary and fiscal policy determine aggregate demand given 
whatever conditions the private sector generates. If austerity politics, for example, imposes limits on fiscal stimulus, in theory at least easy monetary policy can approximate target levels of capacity utilization and unemployment. Austerity politics, of course, is directed as much at easy monetary policy as it is at easy fiscal policy, suggesting that the underlying target of austerity is to maintain enough slack in the economy to produce downward pressure on the wage share. The politics of policy in these circumstances does not depend critically on whether demand is theoretically wageled or profit-led.

Storm buys a bit too much for my taste into the story that it is only the Left that learned the lessons of Keynesianism. It seems to me Reagan, Thatcher \& Co also learned those lessons (maybe more effectively than, say, the Democratic party in the U.S., which tried to run on balancing the budget in the 1980s and 1990s), but deployed them more in line with the austerity economics ambition to keep capacity utilization low enough and unemployment high enough to put chronic downward pressure on the wage share of national income. Storm mentions Kalecki's 1943 paper, which is a very promising starting point, but he doesn't develop that line of thinking fully. Kalecki's paper prophesies a reaction of capitalists in a mixed economy to Keynesian promises of full employment, which seems pretty much what has happened.

It seems to me that social democracy had its broadest political appeal when it combined short-term mitigation of inequality through the welfare state with a long-term promise of transforming production relations through nationalization. When the nationalization of production turned out to be more of a political problem than an asset because it required the social democrats to take responsibility either for slow productivity growth if they protected jobs that changes in technology or demand made redundant, or for firing workers if they didn't, they dropped the longterm vision of nationalization. But this left social democracy pretty much in the position of claiming it could run the capitalist system better than the capitalists, and eventually drifting into the even less appealing position that they could dismantle the welfare state better than the capitalists. At that point you can see why their electoral prospects headed south.

It appears to me that there is pretty strong evidence both for induced technical change (the tendency for high wages to incentivize labor-saving innovation) and the Kaldor-Verdoorn effect (the tendency for rapid growth of output to increase labor efficiency). If anybody cares all that much about absolute standards of living, there ought to be some politics favoring high wages and avoiding stagnant slow growth, but a political movement organized around that idea is strikingly absent from the current political spectrum. (National Income and Product Account concepts such as National Income and Gross Domestic Product have a bias toward measuring real income growth higher than it probably is due to such features as regarding increases in financial fees as increasing production of financial services, and increases in the cost of health services as raising real incomes, with similar dubious effects in other sectors.)

There are more general lessons and questions to be learned from this, and in particular some that are relevant to the US Democratic party's current pickle. Progressive politics does 
depend on operating a mixed economy in such a way that some (preferably profit) income can be diverted in various ways to the parts of the population that are bearing the costs of capital accumulation and creative destruction. But this is not a very exciting political message, and the beneficiaries of the welfare state are easily distracted from its politics by wedge issues.

David Frum, writing regularly in the Atlantic magazine, has some good insights into the resulting stalemate. The reactionary Republicans really only have a program of dismantling the New Deal by privatizing Social Security and trying to wreck whatever other remnants of progressive government they can get their hands on. Privatizing Social Security, however, would politically require funding the benefits owed to current participants in the Social Security system, which would add many trillions of dollars to the national debt. It is unlikely that even if reactionary Republicans somehow managed to get effective control of government policy they would get very far on dismantling Social Security. But, as Frum insists, the Republicans can't win elections on the basis of this program, so they are helpless hostages of a demagogue like Trump, who promises to deliver electoral victory by splitting the Democratic base. Meanwhile the Democrats don't have a clear analysis of what it would mean to operate the mixed economy, and tend to argue over fantasies of universal this and that as their electoral advantages slip away. Where is the Democratic discussion of the proportion of GDP they could hope to mobilize for inequality-reducing social programs through the tax system?

Storm tries to encapsulate this picture through the macroeconomic terminology of wageand profit-led growth and the Non-Accelerating Inflation Rate of Unemployment (which, as far as I can tell, no one takes seriously at this point in terms of macroeconomic policy). Macroeconomic policy is certainly a critical aspect of the political economic mix, since low unemployment rates and robust income growth do much more for inequality and the welfare of low-income households than any combination of welfare-state programs can. At this juncture, however, it's not clear that the Democrats have credible claim to a better macroeconomic policy than Trump.

U.S. Democrats, like European social democrats, need to think through more thoroughly the place of macroeconomic policy in a general strategy for managing the mixed economy that includes the dimensions of income distribution, competition, and labor protection. The welfare state we have now was a response to the conditions of the European and North American economies of the nineteen-fifties and nineteen-sixties, which were still dominated by industrial production. Much employment required firm-specific skills, which made union organization easier and the adjustment of firm compensation and employment policies to the whole worker life-cycle more cost-effective. The main source of fluctuations in worker incomes was the industrial business cycle. But this pattern of employment, and the limitations on inequality in distribution of income inherent in it, is gone with the wind, and can't be recovered by any feasible policy. A successful left-wing politics has to address the real problems of low-income households, in which uncertainty of employment and income are built into job structures, and individual workers have even less bargaining power with employers than their industrial predecessors, and financial predation and 
crisis and constantly escalating costs of health care and education have become the dominant source of income insecurity. None of these developments invalidate the insights of Keynesian economics, but they do create a new context for Keynesian policies. 


\section{Murder on the Occident Express: What Really Killed Social Democracy?}

\section{Thomas Ferguson}

Servaas Storm's lucid and closely reasoned paper about the decline of social democracy is exquisitely timed. It is hard to believe that the double challenge of Covid-19 and climate change will not soon inspire many people to reconsider their attitudes toward states and markets. That I share the misgivings that (Halevi and Kriesler, 2020) and Duncan Foley (2020) voice about the "wage-led" / "profit-led" growth framework Storm employs hardly matters. The paper is very good and anyone reflecting on these questions will want to read it.

That's the good news. The bad news is that this is a short comment on a complicated paper that treats an almost impossibly complex subject. It would be easy to write a study twice as long

just pursuing a few leading issues. All I can do here is comment briefly on a few key points, with no hope of inventorying the relevant literature.

I think that excluding the US from his analysis, as Servaas does in his final version, is not a happy idea. It makes it harder to see some crucial influences on the decline of social democracy. The US never qualified as a truly social democratic state, but the old New Deal party system that ebbed away between the late sixties and the 1973-74 recession did share some important features of the European social democratic models. ${ }^{i}$ But these latter all existed within the framework of the Cold War Pax Americana. As that fell apart, world capital markets opened, and production became much easier to relocate, everything changed in ways models of economic dynamics in a single country cannot catch.

The vast increase in the mobility of capital, both across and out of Europe, was almost certainly the decisive factor in social democracy's crack up. It conferred overwhelming cumulative advantages on business and left labor, which was far less mobile, hopelessly behind - in wage negotiations, political power, social bargaining, even media influence, since the media globalized,

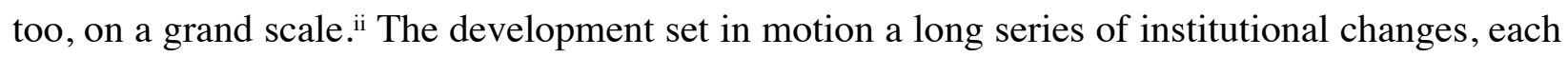
of which can each easily be misunderstood as the key driver of what finally resulted.

Most US economists were slow to grasp the significance of the international economic system's new stage of integration. Solow, Modigliani, and Samuelson, for example, focused mostly on main line Keynesian country models when they thought about macroeconomics. They largely missed international spillovers of monetary policy and the Eurodollar market, the significance of the multinational corporation, and the sweeping implications of financial deregulation, though that's a long argument. 
Kindleberger was closer to the truth, in that he recognized the evolution of the system, though he, like his colleagues, way overestimated the responsiveness of employment markets. iii As it happened, when I started teaching at MIT, I saw he was offering his last course and went and took it. Most of his colleagues had little use for him, which was impossible not to notice. They worked and thought in terms of capitalism-in-one-country-at-a-time models. Francis Bator, the MIT trained Deputy National Security Adviser who functioned as Lyndon Johnson's economic adviser appreciated the emerging complications, but stuck with the basic model, too.

The disaster that engulfed European social democracy started in the US with the classic labor market tightness that arose from the War in Vietnam and Great Society contributions to effective demand. That would have happened with or without international integration or capital or labor-led anything. Demand was too strong. But the new international economic conditions helped transmit the US strong demand around the world, stoking up other systems, especially those in Europe that were keyed to export led growth. In Europe, where that formula still looked like a winning ticket, the result was a disjointed series of wage and currency demolition derbies that sharpened rivalries between national economies and dramatically altered domestic political alliances, as Halevi's series of papers for INET (Halevi, 2019a, 2019b, 2019c) document.

This outsized cyclical movement occurred in the midst of dramatic structural changes that were spawning what now goes loosely under the term "globalization." The balance of payments weakness that troubled the US economy in the fifties turned into a flood of imports, especially from Asia, that destroyed one US industry after another. Rather than fighting, many industries and investors happily switched, leaving the US for greener pastures abroad. They also seized the opportunity these pressures afforded them to press for ever increasing deregulation, lower taxes, and a roll back of the modest New Deal welfare state. ${ }^{\text {iv }}$ Financial deregulation, in turn, dramatically affected how firms organized production. ${ }^{\mathrm{v}}$

Synchronized political business cycles, along with the jockeying for exports that Halevi describes in his papers, then kicked in, leading to even stronger worldwide demand in the Nixon years. That created OPEC, as Adelman and others saw at the time, as well as raising other commodity prices. Ever since the late fifties, as European social democratic parties had become integrated in the system, politicians in both the US and Europe often tried to stimulate economies around election time. That was the fact behind the emergence of the other, Neoclassical theory of the political business cycle. As a graduate student at Princeton, I sat in on Alan Blinder and Edward Tufte's course on political business cycles. The topic was viewed as daring. They had no use for or interest in Kalecki. The focus was on short run electoral calculations in a Keynesian model (Tufte, 1978).

That approach was obsolete even as it became fashionable. The reaction among world business communities to the rise in inflation and (sometimes) labor turbulence was everywhere the same: proclaim a "crisis of democracy," pressure policymakers to tighten monetary policy following elections, which was a costly delay in the super-heated 71-72 period, and cut back on 
fiscal policy. These steps, combined with the oil crisis, gave us the 73-74 recession, the worst since the end of World War II. Under heavy pressure from business lobbies virtually every country tried to throw the costs of the oil price rises on wage earners.

The recycling of the oil surpluses from the Persian Gulf to the developing world, along with changes in telecommunications, ever-increasing financial deregulation, and the US defense buildup made it attractive for major developed country firms to expand into what was then referred to as the Third World, even as Japan's industrial surge continued and the Asian "tigers" began to roar.

Volcker and the Second Oil Shock vastly amplified the spread of austerity policies. By transmitting high interest rates to the whole world, the US rate rise and the "Washington Consensus" ensured that globalization would progress in a climate of austerity for many years. ${ }^{\mathrm{vi}} \mathrm{A}$ vast intensification of pressures on labor and social democratic movements everywhere followed. Given austerity, all sorts of institutional devices to hold wages down became possible in both the US and Europe. Gradually dual economies began to take shape within all the leading developed countries, though the US led the way by far (Temin, 2017) (Taylor, 2020) (Storm, 2017).

Volcker, it is worth noting, was appointed by a Democratic President and social democratic leaders in Europe almost uniformly decided that discretion was the better part of valor when it came to exploring policy alternatives to high unemployment, as Storm emphasizes.

He alludes to a fine and almost unknown work, Labour Party Plc (Osler, 2001), but the UK case hardly stands alone. The absorption and purchase of social democratic party leaders by business that the book described happened in all the major social democratic parties, as well as the US Democratic Party, though documentation of this fact varies by country. Social democratic leaders mostly proved capable of resisting anything except temptation. Tony Blair, Wim Kok, and other European socialists advised or served on the board of many leading business firms. By 2012, many members of the SPD in Germany were surprised to discover that the party's (losing) candidate for Chancellor had received more than a million dollars in speeches from banks and other prominent businesses.

In all of this it is hard to see the relevance of capital or wage-led domestic processes of growth. The system was driven by dramatic changes in government spending (including transfers) and monetary policy in each country, in the context of the internationalization of production and

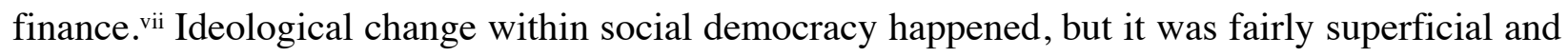
second order. Mostly it rationalized what was actually occurring, usually with a lag - as labor declined, business, especially finance and now big tech, attained increasing power not simply within the system as a whole but within the parties themselves.

If you want to reverse this process you will obviously have to raise the share of wages for a long period of time (Taylor, 2020). That means expanding $\mathrm{G}$ in the extended (including transfers) sense, with accommodating monetary policies, along with investment and tax reforms that actually 
induce investment in people and skills, block tax arbitrage, and move economies onto sustainable growth paths. All of these, obviously, require a change in the balance of power within the political system: effective controls on political money and lobbying. I know Storm believes this too, which is why I think long detours into wages and profit-led growth is a diversion. Just fix the spectrum of political money in a broad sense (Ferguson, Jorgensen, and Chen, 2020) and political and economic reforms that really benefit the population as a whole become possible again.

\section{References}

Ferguson, T. 1984 "Normalcy to New Deal: Industrial Structure, Party Competition, and American Public Policy in the Great Depression," International Organization, Vol. 38, No. 1 (Winter, 1984), pp. 41-94.

Ferguson, T, Jorgensen, P., Chen, J. (2020). "How Much Can the U.S. Congress Resist Political Money? A Quantitative Assessment," Institute for New Economic Thinking Working Paper No. 109. https://doi.org/10.36687/inetwp109

Ferguson, T. and Rogers, J. 1986. Right Turn: The Decline of the Democrats and the Future of American Politics. New York: Hill \& Wang.

Foley, D. 2020 “Comment on Storm.” Institute for New Economic Thinking, Working Paper 122

Galbraith, J. K. 2002 "A Perfect Crime: Inequality in an Age of Globalization," Daedalus, 131, No. 1, pp. 11-25.

Halevi, J. 2019a "The Political Economy of Europe since 1945: A Kaleckian Perspective." Institute for New Economic Thinking Working Paper No. 100

Halevi, J. 2019b "Europe 1957 to 1979: From the Common Market to the European Monetary System." Institute for New Economic Thinking, Working Paper No. 101.

Halevi, J. 2019c "From the EMS to the EMU and...to China," Institute for New Economic Thinking, Working Paper No. 102

Halevi, J. and Kriesler, P. 2020 "Comment on Storm." Institute for New Economic Thinking, Working Paper No. 122

Lazonick, William Sustainable Prosperity in the New Economy: Business Organization and High Tech Employment in the United States Kalamazoo: Upjohn Institute.

Lazonick, W. and Shin, J. 2020 Predatory Value Extraction Oxford: Oxford University Press.

Oseler, D. 2002 Labour Party Plc. London: Mainstream Press. 
Samuelson, Paul. "Where Ricardo and Mill Rebut and Confirm Arguments of Mainstream Economists Supporting Globalization," Journal of Economic Perspectives, 18, No. 3, pp. 135-46.

Storm, S. 2020. “The Economics and Politics of Social Democracy: A Reconsideration," Institute for New Economic Thinking Working Paper No. 122

Storm, S. 2017 “The New Normal: Demand, Secular Stagnation and the Vanishing Middle Class," Institute for New Economic Thinking Working Paper No. 55.

Taylor, L. 2020. Macroeconomic Inequality From Reagan To Trump, Cambridge University Press, in press.

Temin, P. 2017 The Vanishing Middle Class: Prejudice and Power in a Dual Economy. Cambridge, MA: MIT Press.

Tufte, Edward. 1978 Political Control of Elections. Princeton: Princeton University Press 
${ }^{i}$ The comment is meant specifically in the sense of (Ferguson, 1984), which showed how variations in the strength of labor affected party systems and outcomes in democratic states. The New Deal reflected a relatively weak labor movement even at its apex.

${ }^{\text {ii }}$ Storm is clear that some declines in social democratic voting occurred even in the fifties. This point, if pursued, might make some trouble; he plainly thinks the big drivers of social democratic decline came much later. Capital mobility, like the growth of a common market, actually happened in stages, making dating the process in different countries difficult and contentious. Still, iconic events like the decision to introduce the European Monetary System or the Euro and shape the new Europe as a bankers' Europe, eschewing nearly all Keynesian elements, provide important signposts. Note also that increases in exports across Europe were dramatic; those, especially for countries that were not net exporters, surely were important influences on social democratic parties.

iii Only in his late work did Samuelson begin to come to grips with the dimensions of the employment problems. See, e.g., (Samuelson, 2004). That paper shocked quite a few people, though he claimed merely to be reaffirming a point he had made years before.

${ }^{\text {iv }}$ (Ferguson and Rogers, 1986) described the process in detail; for the consequent polarization of American politics, see (Ferguson, 2015).

"See the discussion of financialization and "New Economy business models" in (Lazonick, 2009) or (Lazonick and Shin, 2020).

${ }^{v i}$ Besides (Ferguson and Rogers, 1986), see especially (Galbraith, 2002).

${ }^{\text {vii }}$ Formally and for the record: In the obvious absence of anything approaching effective international economic policy coordination aiming at full employment. This is simply the flip side of the rise of new powers in the international system. 